\title{
Bioleaching Ability of Fungi Isolated from an Indonesian Sulfurous River Sediment
}

\author{
Serafica Btari Christiyani Kusumaningrum ${ }^{1}$, I Wayan Warmada ${ }^{2}$, \\ Wahyu Wilopo ${ }^{2}$, and Endah Retnaningrum ${ }^{3, *}$ \\ ${ }^{1}$ Graduate Student of Biology Faculty, Universitas Gadjah Mada, \\ Jl. Teknika Selatan, Sekip Utara, Yogyakarta 55281, Indonesia \\ ${ }^{2}$ Department of Geological Engineering, Faculty of Engineering, Universitas Gadjah Mada, \\ Jl. Grafika No. 2, Yogyakarta 55281, Indonesia \\ ${ }^{3}$ Faculty of Biology, Universitas Gadjah Mada, \\ Jl. Teknika Selatan, Sekip Utara, Yogyakarta 55281, Indonesia
}

\author{
*Corresponding author: \\ email:endahr@ugm.ac.id \\ Received: April 7, 2019 \\ Accepted: February 22, 2020 \\ DOI: $10.22146 /$ ijc. 44810
}

\begin{abstract}
The unique characteristics of sulfurous river sediment located in Ungaran, Indonesia, are a reservoir of novel fungi with manganese bioleaching properties. Fungi are known to produce metabolic organic acids that have a potential for the industrial application of leaching metal from the ores. This application has high advantages, including low cost, low energy, and creates minimal environmental damage. Therefore, this research was performed to analyze the manganese bioleaching activities of two fungal isolates (KA2B2 and KB4B) from Indonesian sulfurous river sediment on pyrolusite and determine their phenotypic characters. These activities were investigated in terms of changes in fungal biomass, soluble manganese concentration, $p H$ reduction, and organic acid production during 16 days of leaching. Soluble manganese concentrations were measured by atomic absorption spectrometry (AAS), whereas organic acid concentrations were analyzed by high-performance liquid chromatography (HPLC). According to bioleaching investigations, KA2B2 strain was more efficient than KB4B1 strain in extracting manganese from $0.02 \mathrm{~g} / \mathrm{cm}^{3}$ pyrolusite. It also produced higher levels of organic acids, such as oxalic acid and citric acid, than KB4B1 strain, proving that strain of KA2B2 could be used to extract manganese from pyrolusite. Based on the phenotypic characters, both strains were identified as genus Penicillium.
\end{abstract}

Keywords: pyrolusite; soluble manganese; oxalic acid; citric acid

\section{- INTRODUCTION}

Manganese is an important heavy metal that serves several industrial purposes. Due to an increase in its demand for use in industrial products, the development of an effective and environmentally safe method of metal extraction is necessary. Recently, bioleaching has been reported as the most effective, low-cost, and promising green technology for metal extraction. This method involves the activities of microorganism groups, such as chemoautotrophic bacteria (sulfur-oxidizing bacteria), heterotrophic bacteria, and fungi [1-4]. Fungi are a ubiquitous group of microbial communities that play a growing role as agents of geochemical change. Most previous research was conducted to isolate fungi from peculiar habitats such as acids, mine drainage, mining areas, the igneous oceanic crust, and rocks [5-8]. Fungal strains have been reported to extract several heavy metals such as gold, copper, nickel, and lithium by processes of bioleaching [9-11].

Fungal bioleaching processes, which are necessary for mining industry development, involve several mechanisms, including matrix solubilization, complex metal forming results from organic acids or amino acids excretion reaction, reduction of ferric iron mediated by oxalic acid, and metals bioaccumulation by fungal 
mycelia. In addition, fungal bioleaching has advantages over bacterial bioleaching because fungi have a shorter lag phase during growth, the ability to tolerate toxic materials, a faster leaching rate, and capability to grow over a wide range of $\mathrm{pH}$ (from acidic to alkaline conditions) and in sulfurous environments [12-18].

A sulfurous river located in Ungaran, Indonesia, is one of the places that has the unique characteristics of a high sulfur concentration and a wide temperature range. In such sediment ecosystems, fungi can exhibit a variety of tolerance and survival mechanisms. These unique habitats can also serve as a reservoir of novel fungi with extraordinary properties. In consequent, the fungi with the potential for metal extraction could be isolated from these habitats. However, there is no recent study reported indigenous fungi from the Indonesian sulfurous river, which have potency for metals extraction. Therefore, in this study, fungi that have bioleaching ability were isolated from this habitat, and their phenotypic characters determined. Their manganese bioleaching ability was also investigated based on fungal growth, changes in $\mathrm{pH}$ values, manganese solubility, and organic acid production.

\section{- EXPERIMENTAL SECTION}

\section{Materials}

The pyrolusite used in this research was collected and originated from Kliripan, Kulonprogo, Yogyakarta, Indonesia $\left(7^{\circ} 51^{\prime} 48^{\prime \prime} \mathrm{S}-110^{\circ} 07^{\prime} 00^{\prime \prime} \mathrm{E}\right)$. The ore was dry ground to a mean particle diameter of 0.1-0.2 mm [1920]. The mineralogical components of the ore samples were analyzed as $25 \% \mathrm{Mn}, 30.4 \% \mathrm{Fe}$, and $34.0 \% \mathrm{~S}$. These samples were subsequently used for bioleaching experiments. The second set of sediment samples were collected from the sulfurous river in Ungaran, Middle Java, Indonesia. These samples were kept at $4{ }^{\circ} \mathrm{C}$ and used only for isolating fungi.

\section{Instrumentation}

The $\mathrm{pH}$ of the leachate was measured by using a digital $\mathrm{pH}$ meter (Metrohm). Dissolved manganese was analyzed by using a flame atomic absorption spectrophotometer (Hitachi, Z-2000) [21]. The organic acid components were investigated using high- performance liquid chromatography (HPLC, Knauer) equipped with a Zorbax C18 column $(250 \mathrm{~mm} \times 4.6 \mathrm{~mm})$ and a detector with diode array at $210 \mathrm{~nm}$. The mobile phase was composed of $0.01 \mathrm{~mol} / \mathrm{L} \mathrm{KH}_{2} \mathrm{PO}_{4}-\mathrm{H}_{3} \mathrm{PO}_{4}(\mathrm{pH}$ 2.6) and $3 \%$ methanol $(\mathrm{v} / \mathrm{v})$ at $0.5 \mathrm{~mL} / \mathrm{min}$ flow rate. Finally, to quantify organic acids, an external standard method has been used [22].

\section{Procedure}

\section{Fungal isolation and screening}

One gram of the second sample was diluted in $9 \mathrm{~mL}$ sterilized $\mathrm{H}_{2} \mathrm{O}$ and was inoculated into sucrose liquid medium with a pulp density of pyrolusite of $0.02 \mathrm{~g} / \mathrm{cm}^{3}$ (final pH: 6.0). The mixture was incubated at $30^{\circ} \mathrm{C}$ with rotary shaking at $120 \mathrm{rpm}$. The sucrose liquid medium consisted of the following composition $\left(\mathrm{gL}^{-1}\right)$ : sucrose (100), $\mathrm{NaNO}_{3}$ (1.5), $\mathrm{KH}_{2} \mathrm{PO}_{4}(0.5), \mathrm{MgSO}_{4} \cdot 7 \mathrm{H}_{2} \mathrm{O}$ (0.025), $\mathrm{KCl}$ (0.025), and yeast extract (1.6) [9]. After 7 days of incubation, it was plated on sucrose solid medium with a pulp density of pyrolusite of $0.02 \mathrm{~g} / \mathrm{cm}^{3}$. This culture was incubated for 7 days until single colonies as pure cultures of the fungal strain were obtained. Sixteen pure strains were isolated from the second sample and then transferred into a sterilized liquid sucrose medium with a pulp density of pyrolusite of $0.02 \mathrm{~g} / \mathrm{cm}^{3}$. Through analyzing shifts in media $\mathrm{pH}$ values, fungal strains were selected within 7 days based on their ability to significantly lower the $\mathrm{pH}$ of the medium from more than 7.3 to 3.0. These strains were selected for further experiments.

\section{Bioleaching investigations}

Two fungal strains selected (KA2B2 and KB4B1) were incubated on potato dextrose agar slants for 7 days. After incubation, their spores were washed from the cultures using a physiological saline sterile solution $\left(9 \mathrm{gL}^{-1}\right.$ $\mathrm{NaCl})$. Spores were enumerated under a microscope at $400 \times$ magnification using a hemocytometer of $1 \mathrm{~mm}$ depth, and their number was determined at about $10^{7}$ spores/mL with a physiological saline sterile solution [23].

One milliliter part of the spore suspension was inoculated into $100 \mathrm{~mL}$ of sterilized sucrose medium with a pulp density of pyrolusite of $0.02 \mathrm{~g} / \mathrm{cm}^{3}$ in a $250 \mathrm{~mL}$ 
Erlenmeyer flask. Each strain was incubated at $30^{\circ} \mathrm{C}$ and $120 \mathrm{rpm}$ for 16 days. On experimental days $0,2,4,6,8,10$, 12,14 , and 16 , samples were collected from each flask, centrifuged for $10 \mathrm{~min}$ at $5000 \mathrm{rpm}$ and filtered through a $0.42 \mu \mathrm{m}$ Whatman membrane filter. The filtered samples were then measured for their value of $\mathrm{pH}$, soluble manganese concentration, and organic acids. Whereas, the filter paper containing mycelia was then dried at $80^{\circ} \mathrm{C}$ for $24 \mathrm{~h}$ for fungal biomass measurements.

\section{Phenotypic characterization}

Both strains were further observed for their phenotypic characters based on a macroscopic and microscopic investigation in two types of identification media: Czapek yeast auto lysate (CYA) and malt extract auto lysate (MEA). Fungal cultures were incubated following the recommended of previously mycology researches [24-25]. The macroscopic observations studied included the diameter of the colony, the color of obverse and reverse colonies, and the presence or absence of exudates. Whereas, microscopic characters of the fungal isolates were observed using an optical microscope.

\section{Statistical analysis}

The data were analyzed using a Statistical Analysis Systems (SAS 9.4, SAS Institute, Inc., Cary, NC, USA) software package. Statistical analysis differences between average values were analyzed using analysis of variance (ANOVA) and Duncan Multiple Range Test (DMRT) method, respectively. The results were reported as means of three replicates. Their mean values were then compared using a significance level of $\mathrm{p}<0.05$.

\section{- RESULTS AND DISCUSSION}

In this investigation, two fungal cultures (strain $\mathrm{KA} 2 \mathrm{~B} 2$ and $\mathrm{KB} 4 \mathrm{~B}$ ) were isolated and selected from the five strains for subsequent observations. These selections were evaluated by analyzing shifts in media $\mathrm{pH}$ values produced during acidolysis by fungal strains. As reported by previous researchers, the main mechanism of bioleaching by fungal strains is the acidolysis of organic acids $[9,26]$. Both filamentous fungal strains were observed to significantly lower the $\mathrm{pH}$ of the medium from more than 7.3 to 3.0 in 7 days.

\section{Changes in Fungal Biomass, pH, and Manganese Concentration during the Bioleaching Process}

Bioleaching experiments were conducted at $\mathrm{pH} 6$ and $30{ }^{\circ} \mathrm{C}$ with a particle size of $0.1-0.2 \mathrm{~mm}$ and agitation at $120 \mathrm{rpm}$. The initial inoculum size was $10^{7}$ spores $/ \mathrm{mL}$, the pulp densities of pyrolusite were $0.02 \mathrm{~g} / \mathrm{cm}^{3}$ and the incubation time was 16 days. In this research, the two fungal strain Penicillium KA2B2 and Penicillium KB4B1 were selected and compared as bioleaching agents. Fig. 1 compares the changes in fungal biomass, $\mathrm{pH}$, and yield of extracted manganese between the two strains during 16 days of bioleaching investigations.

Penicillium KA2B2 yielded larger biomass and had a shorter lag phase compared with Penicillium KB4B1. During 4 days of Penicillium KA2B2 growth, the biomass had a maximum value of $30 \mathrm{~g} / \mathrm{L}$, and the $\mathrm{pH}$ of the medium steadily decreased, reaching 1.5 on the $16^{\text {th }}$ day. This increase in the biomass value and decrease in $\mathrm{pH}$ at the fourth day indicated that Penicillium KA2B2 was in its logarithmic growth phase. A similar trend of increasing biomass and declining $\mathrm{pH}$ values during the logarithmic growth phase of Penicillium KA2B2 was also observed in the culture of Penicillium KB4B1. In comparison, Penicillium KB4B1 took longer to reach the logarithmic growth phase, which was observed at 6 days' incubation. The maximum value of its fungal biomass was $18 \mathrm{~g} / \mathrm{L}$, and the minimum $\mathrm{pH}$ was 2.6 .

The acidification phenomenon in both cultures led to manganese solubilization, as shown by the increase in their yield of leached manganese. Penicillium KA2B2 extracted as much as $25 \%$ of the manganese from pyrolusite under optimal conditions at 8 days' incubation. On the other hand, Penicillium KB4B1 extracted less (20\%) manganese from pyrolusite under optimal conditions at 10 days' incubation. As reported by previous researchers, the phenomenon of culture acidification is caused by organic acids provided by strains, which are important in the metal bioleaching process. These acids could supply both protons and metal-complexing anions, leading to free metal cations released. The reactions between organic acids (oxalic acid, 

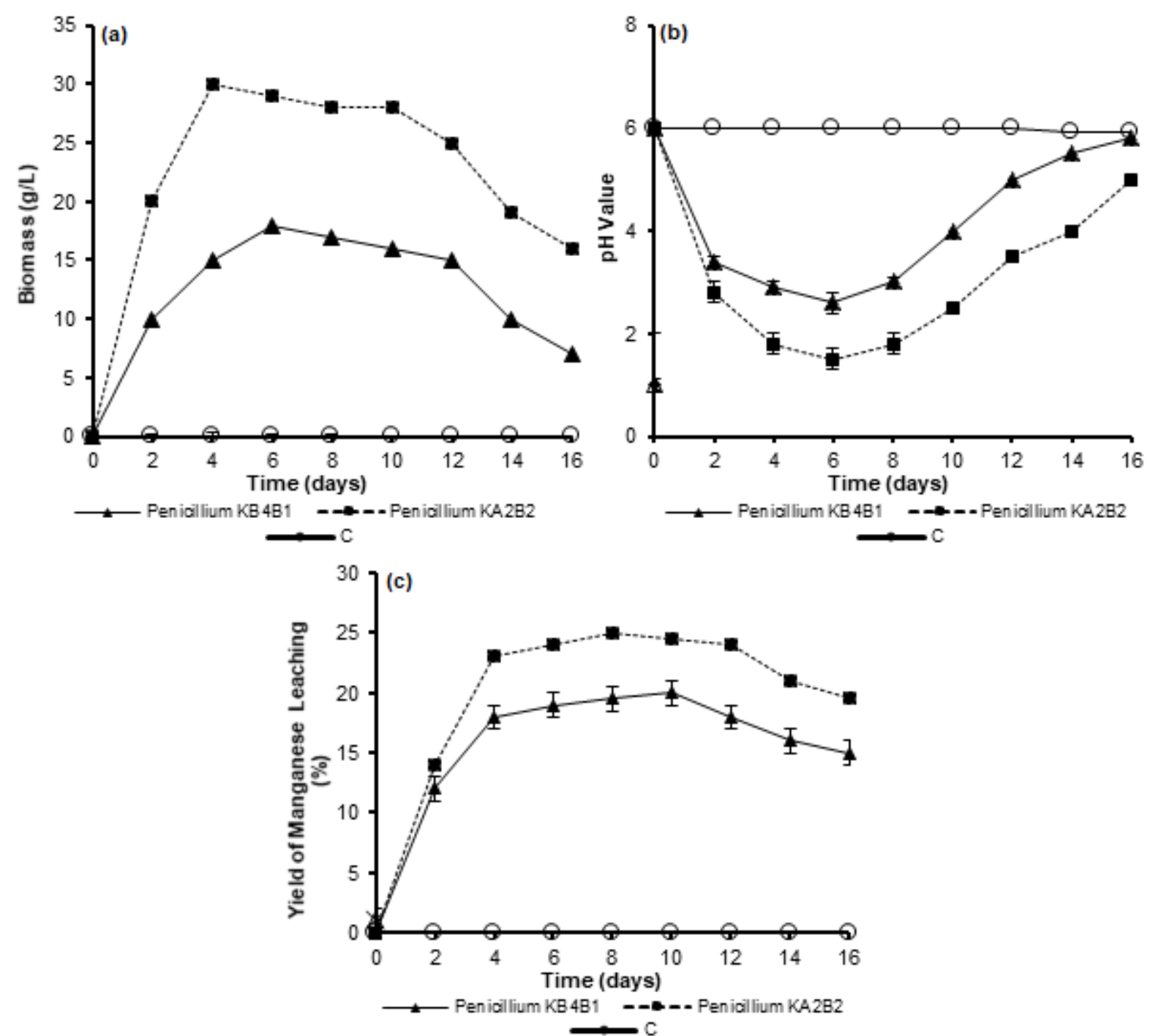

Fig 1. Changes in biomass (a); $\mathrm{pH}$ value (b); and manganese yield (c); between Penicillium KB4B1 and Penicillium $\mathrm{KA} 2 \mathrm{~B} 2$ at a pulp density of pyrolusite of $0.02 \mathrm{~g} / \mathrm{cm}^{3}$ during 16 days of leaching

citric acid) and metallic ion $\left(\mathrm{M}^{\mathrm{n}+}\right)$ are described below [27-28].

The dissociation $(1,2)$ and complexation reactions $(2,3)$ of oxalic acid are:

$\mathrm{C}_{2} \mathrm{H}_{2} \mathrm{O}_{4} \rightarrow \mathrm{C}_{2} \mathrm{HO}_{4}^{-}+\mathrm{H}^{+}\left(\mathrm{pK}_{\mathrm{a} 1}=1.25\right)$

$\mathrm{C}_{2} \mathrm{HO}_{4}^{-} \rightarrow \mathrm{C}_{2} \mathrm{O}_{4}^{2-}+\mathrm{H}^{+}\left(\mathrm{pK}_{\mathrm{a} 2}=4.14\right)$

$\left.\mathrm{n}\left[\mathrm{C}_{2} \mathrm{HO}_{4}^{-}\right]+\mathrm{M}^{\mathrm{n}+} \rightarrow \mathrm{M}^{-} \mathrm{C}_{2} \mathrm{HO}_{4}\right]_{\mathrm{n}}$ (Oxalic metallic complex)

$\mathrm{n}\left[\mathrm{C}_{2} \mathrm{O}_{4}^{2-}\right]+2 \mathrm{M}^{\mathrm{n}+} \rightarrow \mathrm{M}_{2}\left[\mathrm{C}_{2} \mathrm{O}_{4}\right]_{\mathrm{n}}$ (Oxalic metallic complex) (4)

Whereas the dissociation $(5,6,7)$ and complexation reactions $(8,9,10)$ of citric acid are:

$\mathrm{C}_{6} \mathrm{H}_{8} \mathrm{O}_{7} \rightarrow \mathrm{C}_{6} \mathrm{H}_{7} \mathrm{O}_{7}^{-}+\mathrm{H}^{+}\left(\mathrm{pK}_{\mathrm{a} 1}=3.09\right)$
$\mathrm{C}_{6} \mathrm{H}_{7} \mathrm{O}_{7}^{-} \rightarrow \mathrm{C}_{6} \mathrm{H}_{6} \mathrm{O}_{7}^{2-}+\mathrm{H}^{+}\left(\mathrm{pK}_{\mathrm{a} 2}=4.75\right)$

$\mathrm{C}_{6} \mathrm{H}_{6} \mathrm{O}_{7}^{2-} \rightarrow \mathrm{C}_{6} \mathrm{H}_{5} \mathrm{O}_{7}^{3-}+\mathrm{H}^{+}\left(\mathrm{pK}_{\mathrm{a} 2}=6.40\right)$

$\left.\mathrm{n}\left[\mathrm{C}_{6} \mathrm{H}_{7} \mathrm{O}_{7}^{-}\right]+\mathrm{M}^{\mathrm{n}+} \rightarrow \mathrm{M}^{\mathrm{C}} \mathrm{C}_{6} \mathrm{H}_{7} \mathrm{O}_{7}\right]_{\mathrm{n}}$ (Citric metallic complex)

$\mathrm{n}\left[\mathrm{C}_{6} \mathrm{H}_{6} \mathrm{O}_{7}^{2-}\right]+2 \mathrm{M}^{\mathrm{n}+} \rightarrow \mathrm{M}_{2}\left[\mathrm{C}_{6} \mathrm{H}_{6} \mathrm{O}_{7}\right]_{\mathrm{n}}$ (Citric metallic complex) (9)

$\mathrm{n}\left[\mathrm{C}_{6} \mathrm{H}_{5} \mathrm{O}_{7}^{3-}\right]+3 \mathrm{M}^{\mathrm{n}+} \rightarrow \mathrm{M}_{3}\left[\mathrm{C}_{6} \mathrm{H}_{5} \mathrm{O}_{7}\right]_{\mathrm{n}}$ (Citric metallic complex) (10)

Organic acid analysis by HPLC revealed that the

Penicillium KA2B2 culture reached optimum production of citric acid and oxalic acid at 13.5 and $17 \mathrm{mmol} / \mathrm{L}$, respectively. In contrast, the maximum production of citric acid and oxalic acid of Penicillium KB4B1 were 5 and $8 \mathrm{mmol} / \mathrm{L}$, respectively (Fig. 2). 

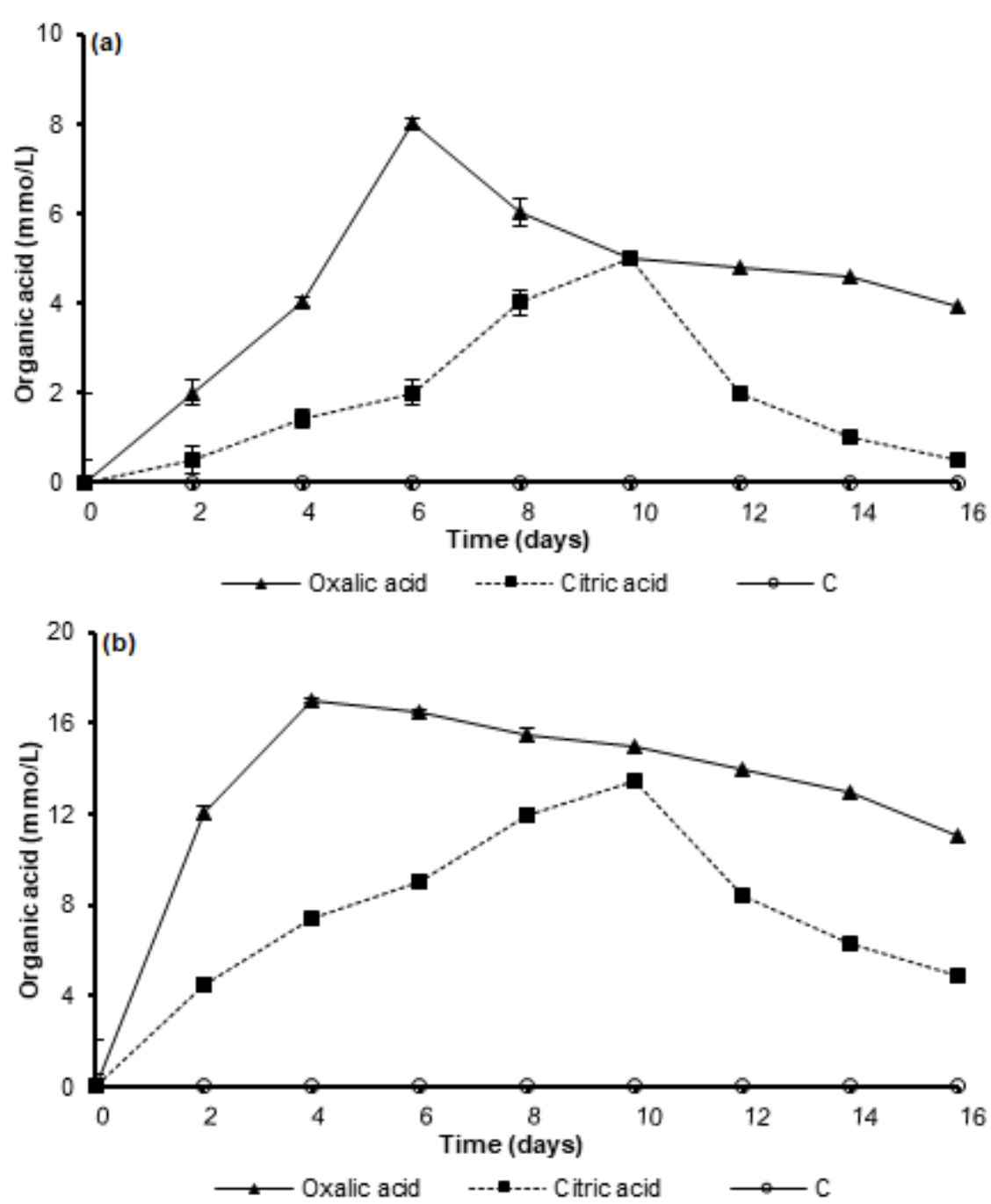

Fig 2. Organic acid production in Penicillium KB4B1 (a) and Penicillium KA2B2 (b) at pulp densities of pyrolusite of $0.02 \mathrm{~g} / \mathrm{cm}^{3}$ in the 16-day leaching process

There were similar trends of oxalic acid and citric acid secretion in Penicillium KA2B2 and Penicillium KB4B1. Within the logarithmic growth phase of these fungi, the production of oxalic acid was highly increased, and then slowly decreased; however, a significant amount of oxalic acid remained in the medium at the end of the incubation. In contrast, the production of citric acid by both strains occurred within the stationary phase, which was characterized by a decreased rate of growth in these fungi. In comparison with $\mathrm{pH}$ measurements, it is clear that the increase in citric acid and oxalic acid secretion by the two strains occurred at $\mathrm{pH}$ values less than 3 . When the $\mathrm{pH}$ of the medium measured was above $\mathrm{pH} 3$, acid production was reduced.
Oxalic acid biosynthesis from glucose occurs when oxaloacetate is hydrolyzed to oxalate and acetate, catalyzed by cytosolic oxaloacetase, while citric acid is formed as an intermediate in a cycle of tricarboxylic acids involving a polysaccharide such as sucrose [29]. Therefore, sucrose present in the medium during the bioleaching experiment was used as a substrate by the strain for oxalic acid and citric acid biosynthesis. Glucose was first released from sucrose, then absorbed and catabolized to two molecules of pyruvate. In the following step, it was converted into oxaloacetate and acetyl-CoA, and finally, citric acid formed by condensation of these two precursors, which was then secreted from mitochondria and mycelia [30-32]. From 
these results, it was clear that the increase in citric acid production by the cultures was followed by a reduction of the concentration of oxalic acid present in the cultures.

Compared to previous studies, both fungi were about $54 \%$ lower in extracting manganese than Aspergillus niger PTCC 5210 isolated from mining deposits in India [29]. Those fungi were also $22 \%$ lower in extracting metals than Penicillium chrysogenum Y5 isolated from heavy metal contaminated areas [33]. In this study, the low ability of metal extraction from both fungi due to the optimization processes of bioleaching has not been done. Optimization of the parameters that enhanced fungal bioleaching was related to their production of metabolic organic acids, including organic carbon, nitrogen, phosphorous, micronutrient $\left(\mathrm{MgSO}_{4}\right.$ and $\left.\mathrm{MnSO}_{4}\right)$, and aeration.

\section{Phenotypic Characters of Fungi}

For phenotypic identification, fungal isolates were characterized according to previously researchers [24-25]. Macroscopic observations showed heterogeneity between the fungal isolates that being examined (Table 1). The data obtained exhibit that colony diameters of fungal strain KA2B2 varied over a wide range on different agar media: from $3.6 \mathrm{~mm}$ (CYA) to $14.3 \mathrm{~mm}$ (MEA). In addition, the examined fungal cultures displayed variations in surface and reverse colony colors. Strain KA2B2 had a green to the grey surface and orange to bright yellow colony color on CYA. Its surface and reverse colony colors on MEA were green and orange to bright yellow, respectively.

Observation of fungal microscopic characters such as conidiophore branching and its elements are key to the identification of fungi. Two types of fungal conidiophores, metulae, phialides, conidia, and stipe characters, were observed (Table 2). Fungal strain KA2B2 had a mono-verticillate conidiophore branching pattern. The metulae had a compact terminal character. The type of fungal phialides was ampuliform. The conidia size was less than $10 \mu \mathrm{m}$, with a globose and smooth morphology. Fungal strain KB4B1 also had a mono-verticillate conidiophore branching pattern. The metulae had a tuberculate character. The fungal phialides were cylindrical and short with a wide neck. The conidia size was also less than $10 \mu \mathrm{m}$, with a globose and smooth morphology. Thus, based on both macroscopic and microscopic investigations, both of strain $\mathrm{KA} 2 \mathrm{~B} 2$ and $\mathrm{KB} 4 \mathrm{~B} 1$ was identified as genus Penicillium.

\section{- CONCLUSION}

Penicillium KA2B2 isolated from Indonesian sulfurous river sediment is highly efficient for manganese extraction with a pulp density of pyrolusite of $0.02 \mathrm{~g} / \mathrm{cm}^{3}$. The culture extracted manganese by producing oxalic acid and citric acid from the sucrose in the medium. These investigations indicate that oxalic acid

Table 1. Macroscopic characters of two selected fungi isolated from sulfurous river sediment

\begin{tabular}{lllcccc}
\hline \multirow{2}{*}{ Strain } & \multicolumn{3}{c}{ On CYA } & \multicolumn{3}{c}{ On MEA } \\
\cline { 2 - 6 } & $\begin{array}{c}\text { Surface colony } \\
\text { color }\end{array}$ & $\begin{array}{c}\text { Reverse colony } \\
\text { color }\end{array}$ & $\begin{array}{c}\text { Diameter } \\
(\mathrm{mm})\end{array}$ & $\begin{array}{c}\text { Surface colony } \\
\text { color }\end{array}$ & $\begin{array}{c}\text { Reverse colony } \\
\text { color }\end{array}$ & $\begin{array}{c}\text { Diameter } \\
(\mathrm{mm})\end{array}$ \\
\hline KA2B2 & Green-gray & $\begin{array}{c}\text { Orange to bright } \\
\text { yellow }\end{array}$ & 3.6 & Green & $\begin{array}{c}\text { Orange to } \\
\text { bright yellow }\end{array}$ & 14.3 \\
KB4B1 & Dark green & Green & 33.3 & Dark green & Yellow & 33.3 \\
\hline
\end{tabular}

Table 2. Microscopic characters of two selected fungi isolated from sulfurous river sediment

\begin{tabular}{|c|c|c|c|c|c|}
\hline Strain & $\begin{array}{c}\text { Conidiophore } \\
\text { Branching Pattern }\end{array}$ & Metulae & Phialide & Conidia & Stipes \\
\hline KA2B2 & Mono-verticillate & compact terminal & Ampuliform & $\begin{array}{l}<10 \mu \mathrm{m}, \text { globose, } \\
\text { smooth-walled }\end{array}$ & $\begin{array}{l}\text { Rather long, smooth- } \\
\text { walled, vesiculate }\end{array}$ \\
\hline KB4B1 & Mono-verticillate & tuberculate & $\begin{array}{l}\text { Cylindrical, short, } \\
\text { and wide neck }\end{array}$ & $\begin{array}{l}<10 \mu \mathrm{m} \text {, globose, } \\
\text { smooth-walled }\end{array}$ & Relatively short \\
\hline
\end{tabular}


and citric acid contribute significantly to manganese leaching from pyrolusite. This strain is strongly recommended for further studies in field observations.

\section{- ACKNOWLEDGMENTS}

This research was financially supported by KEMENRISTEK DIKTI Indonesia with the Research Implementation Letter No: 173/UN1/DITLIT/DITLIT/LT/2018. We express our thanks to technicians from Microbiology and Falitma Laboratory, Biology Faculty, and also Laboratorium Penelitian Pusat Terpadu, Universitas Gadjah Mada, Yogyakarta, Indonesia.

\section{- REFERENCES}

[1] Fonti, V., Dell'anno, A., and Beolchini, F., 2016, Does bioleaching represent a biotechnological strategy for remediation of contaminated sediments?, Sci. Total Environ., 563-564, 302-319.

[2] Pathak, A., Morrison, L., and Healy, M.G., 2017, Catalytic potential of selected metal ions for bioleaching, and potential techno-economic and environmental issues: A critical review, Bioresour. Technol., 229, 211-221.

[3] Gu, T., Rastegar, S.O., Mousavi, S.M., Li, M., and Zhou, M., 2018, Advances in bioleaching for recovery of metals and bioremediation of fuel ash and sewage sludge, Bioresour. Technol., 261, 428-440.

[4] Retnaningrum, E., and Wilopo, W., 2019, Pyrolusite bioleaching by an indigenous Acidithiobacillus sp. KL3 isolated from an Indonesian sulfurous river sediment, Indones. J. Chem., 19 (3), 712-719.

[5] Vázquez-Campos, X., Kinsela, A.S., Waite, T.D., Collins, R.N., and Neilan, B.A., 2014, Fodinomyces uranophilus gen. nov. sp. nov. and Coniochaeta fodinicola sp. nov., two uranium mine-inhabiting Ascomycota fungi from northern Australia, Mycologia, 106 (6), 1073-1089.

[6] Ivarsson, M., Bengtson, S., and Neubeck, A., 2016, The igneous oceanic crust - Earth's largest fungal habitat?, Fungal. Ecol., 20, 249-255.

[7] Gadd, G.M., 2017, Fungi, rocks and minerals, Elements, 13 (3), 171-176.
[8] Ferreira, P.C., Pupin, B., and Rangel, D.E.N., 2018, Stress tolerance of soil fungal communities from native Atlantic forests, reforestations, and a sand mining degraded area, Fungal Biol., 122 (6), 400409.

[9] Madrigal-Arias, J.E., Argumedo-Delira, R., Alarcón, A., Mendoza-López, M.R., GarcíaBarradas, O., Cruz-Sánchez, J.S., Ferrera-Cerrato, R., and Jiménez-Fernández, M., 2015, Bioleaching of gold, copper and nickel from waste cellular phone PCBs and computer gold finger motherboards by two Aspergillus niger strains, Braz. J. Microbiol., 46 (3), 707-713.

[10] Kim, M.J., Seo, J.Y., Choi, Y.S., and Kim, G.H., 2016, Bioleaching of spent $\mathrm{Zn}-\mathrm{Mn}$ or $\mathrm{Ni}-\mathrm{Cd}$ batteries by Aspergillus species, Waste Manage., 51, 168-173.

[11] Bahaloo-Horeh, N., Mousavi, S.M., and Baniasadi, M., 2018, Use of adapted metal tolerant Aspergillus niger to enhance bioleaching efficiency of valuable metals from spent lithium-ion mobile phone batteries, J. Cleaner Prod., 197, 1546-1557.

[12] Li, Q., Csetenyi, L., Paton, G.I., and Gadd, G.M., 2015, $\mathrm{CaCO}_{3}$ and $\mathrm{SrCO}_{3}$ bioprecipitation by fungi isolated from calcareous soil, Environ. Microbiol., 17 (8), 3082-3097.

[13] Grum-Grzhimaylo, A.A., Georgieva, M.L., Bondarenko, S.A., Debets, A.J.M., and Bilanenko, E.N., 2016, On the diversity of fungi from soda soils, Fungal Divers., 76, 27-74.

[14] Boldt-Burisch, K., and Naeth, M.A., 2017, Early colonization of root associated fungal communities on reclamation substrates at a diamond mine in the Canadian Sub-Arctic, Appl. Soil Ecol., 110, 118-126.

[15] Xu, H.B., Tsukuda, M., Takahara, Y., Sato, T., Gu, J.D., and Katayama, Y., 2018, Lithoautotrophical oxidation of elemental sulfur by fungi including Fusarium solani isolated from sandstone Angkor temples, Int. Biodeterior. Biodegrad., 126, 95-102.

[16] Gholipour, S., Mehrkesh, P., Azin, E., Nouri, H., Rouhollahi, A.A., and Moghimi, H., 2018, Biological treatment of toxic refinery spent sulfidic 
caustic at low dilution by sulfur-oxidizing fungi, $J$. Environ. Chem. Eng., 6 (2), 2762-2767.

[17] Şener, B., Aksoy, D.Ö., Çelik, P.A., Toptaş, Y., Koca, S., Koca, H., and Çabuk, A., 2018, Fungal treatment of lignites with higher ash and sulphur contents using drum type reactor, Hydrometallurgy, 182, 64-74.

[18] Sutcliffe, B., Chariton, A.A., Harford, A.J., Hose, G.C., Greenfield, P., Midgley, D.J., and Paulsen, I.T., 2018, Diverse fungal lineages in subtropical ponds are altered by sediment-bound copper, Fungal Ecol., $34,28-42$.

[19] Mehta, K.D., Das, C., Kumar, R., Pandey, B.D., and Mehrotra, S.P., 2010, Effect of mechano-chemical activation on bioleaching of Indian Ocean nodules by a fungus, Miner. Eng., 23 (15), 1207-1212.

[20] Chiang, Y.W., Santos, R.M., Monballiu, A., Ghyselbrecht, K., Martens, J.A., Mattos, M.L.T., Van Gerven, T., and Meesschaert, B., 2013, Effects of bioleaching on the chemical, mineralogical and morphological properties of natural and wastederived alkaline materials, Miner. Eng., 48, 116-125.

[21] Khayatian, G., Moradi, M., and Hassanpoor, S., 2018, $\mathrm{MnO}_{2} / 3 \mathrm{MgO}$ nanocomposite for preconcentration and determination of trace copper and lead in food and water by flame atomic absorption spectrometry, J. Anal Chem., 73, 470-478.

[22] Vilanova, L., Viñas, I., Torres, R., Usall, J., BuronMoles, G., and Teixidó, N., 2014, Acidification of apple and orange hosts by Penicillium digitatum and Penicillium expansum, Int. J. Food Microbiol., 178, 39-49.

[23] Gillot, G., Jany, J.L., Poirier, E., Maillard, M.B., Debaets, S., Thierry, A., Coton, E., and Coton, M., 2017, Functional diversity within the Penicillium roqueforti species, Int. J. Food Microbiol., 241, 141-150.

[24] Pitt, J.I., and Hocking, A.D., 2009, Fungi and Food Spoilage, Springer, Boston, MA.

[25] Visagie, C.M., Houbraken, J., Frisvad, J.C., Hong, S.B., Klaassen, C.H.W., Perrone, G., Seifert, K.A.,
Varga, J., Yaguchi, T., and Samson, R.A., 2014, Identification and nomenclature of the genus Penicillium, Stud. Mycol., 78, 343-371.

[26] Golmohammadzadeh, R., Faraji, F., and Rashchi, F., 2018, Recovery of lithium and cobalt from spent lithium ion batteries (LIBs) using organic acids as leaching reagents: A review, Resour. Conserv. Recycl., 136, 418-435.

[27] Qu, Y., Lian, B., Mo, B., and Liu, C., 2013, Bioleaching of heavy metals from red mud using Aspergillus niger, Hydrometallurgy, 136, 71-77.

[28] Xu, T.J., Ramanathan, T., and Ting, Y.P., 2014, Bioleaching of incineration fly ash by Aspergillus niger - precipitation of metallic salt crystals and morphological alteration of the fungus, Biotechnol. Rep., 3, 8-14.

[29] Mohanty, S., Ghosh, S., Nayak, S., and Das, A.P., 2017, Bioleaching of manganese by Aspergillus sp. isolated from mining deposits, Chemosphere, 172, 302-309.

[30] Panda, S.K., Mishra, S.S., Kayitesi, E., and Ray, R.C., 2016, Microbial-processing of fruit and vegetable wastes for production of vital enzymes and organic acids: Biotechnology and scopes, Environ. Res., 146, 161-172.

[31] Liu, J., Li, J., Shin, H., Liu, L., Du, G., and Chen, J., 2017, Protein and metabolic engineering for the production of organic acids, Bioresour. Technol., 239, 412-421.

[32] Yang, L., Lübeck, M., and Lübeck, P.S., 2017, Aspergillus as a versatile cell factory for organic acid production, Fungal Biol. Rev., 31 (1), 33-49.

[33] Xia, M.C., Bao, P., Liu, A.J., Zhang, S.S., Peng, T.J., Shen, L., Yu, R.L., Wu, X.L., Li, J.K., Liu, Y.D., Chen, M., Qiu, G.Z., and Zeng, W.M., 2018, Isolation and identification of Penicillium chrysogenum strain Y5 and its copper extraction characterization from waste printed circuit boards, J. Biosci. Bioeng., 126 (1), 78-87. 